\title{
Performance of National and International Level Sports Personnel and its association with Physical and Physiologieal Characteristics, and Nutritional Aspects
}

by

Vindya Ganegama Arachchi.

M.Phil 
Performance of National and International Level Sports

Personnel and its association with Physical and

Physiological Characteristics, and Nutritional Aspects.

by

Vindya Ganegama Arachchi.

Thesis submitted to the University of Sri Jayewardenepura for the award of the Degree of Master of Philosophy in Medical Science on 30-12-2011. 
I certify that the candidate has incorporated all corrections, amendments an additions recommended by the examiners.

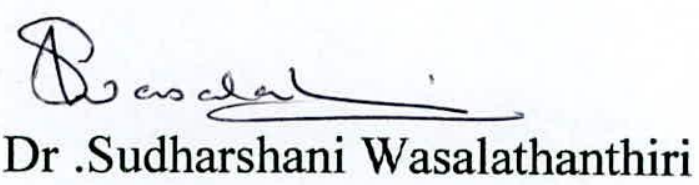




\section{Declaration}

The work described in this thesis was carried out by me under the supervision of Dr.P.T.R.Makuloluwa and Dr.Sudharshani Wasalathanthiri and a report on this has not been submitted in whole or in part to any university or any other institution for another Degree/Diploma.

Date $24 \cdot 12.2012$.

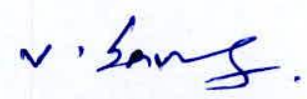

Signature 
We certify that the above statement made by the candidate is true and that this thesis is suitable for submission to the University for the purpose of evaluation.

\author{
P.T.R. Makuloluowa \\ Dr.P.T.R. Makuloluwa
}

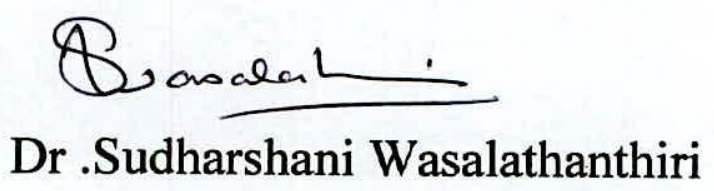


Dedicated to my parents, my husband Ajith,

daughter Yasasvi and son Yenul 


\section{Table of contents}

List of tables

List of figures

$\begin{array}{lll}\text { Acknowledgements } & \text { III }\end{array}$

$\begin{array}{ll}\text { Abstract IV } & \text { IV }\end{array}$

$\begin{array}{lll}\text { 1. Introduction } & \text { Page } & 1\end{array}$

1.1 General 1

1.2 Physical and physiological importance in performance 2

1.2.1 Cardiovascular changes in exercise 3

1.2.2 Respiratory changes in exercise 4

1.2.3 Muscle, the functional unit in exercise 5

$\begin{array}{lll}\text { 1.2.4 Performance characteristics } & 6\end{array}$

$\begin{array}{lll}\text { 1.2.5 Nutritional requirements in exercise } & 7\end{array}$

$\begin{array}{lll}1.3 & \text { Justification } & 8\end{array}$

$\begin{array}{lll}1.4 & \text { Objectives } & 9\end{array}$

1.4.1 General objective 9

$\begin{array}{lll}\text { 1.4.2 Specific objective } & 10\end{array}$

2. Literature Review 11

2.1 Anthropometric measurements in sports personnel 11

2.2 Cardiovascular changes in sports personnel 12

$\begin{array}{lll}2.3 & \text { Respiratory changes in sports personnel } & 14\end{array}$

2.4 Physical and performance characteristics related to sports 16 
2.5 Nutrition and Performance

$\begin{array}{lr}\text { 3. Materials and Methods } & 20\end{array}$

$\begin{array}{lll}3.1 & \text { Study design and Setting } & 20\end{array}$

$\begin{array}{lll}3.2 & \text { Study population } & 20\end{array}$

3.3 Sample of study 20

3.3.1 Short distance athletes $\quad 21$

3.3.2 Swimmers (sprint) 22

$\begin{array}{lll}\text { 3.3.3 Volleyball players } & 23\end{array}$

$\begin{array}{lll}3.4 & \text { Study variables } & 24\end{array}$

$\begin{array}{lll}3.5 & \text { Study Instruments } & 29\end{array}$

$\begin{array}{ll}\text { 3.6 Data collection } & 30\end{array}$

3.6.1 Height 31

$\begin{array}{lll}3.6 .2 & \text { Weight } & 31\end{array}$

3.6.3 Body mass index $\quad 32$

3.6.4 Percentage of Body fat 33

3.6.5 Cardio pulmonary exercise tests $\quad 34$

$\begin{array}{lll}\text { 3.6.6 Strength } & 35\end{array}$

$\begin{array}{lll}3.6 .7 & \text { Power } & 35\end{array}$

$\begin{array}{lll}3.6 .8 & \text { Flexibility } & 36\end{array}$

$\begin{array}{lll}3.6 .9 & \text { Endurance } & 36\end{array}$

$\begin{array}{lll}3.6 .10 & \text { Nutritional status } & 36\end{array}$

$\begin{array}{lll}\text { 3.6.11 Energy expenditure } & 38\end{array}$

$\begin{array}{lll}3.6 .12 & \text { Performance } & 39\end{array}$

$\begin{array}{lll}3.7 & \text { Analysis of data } & 39\end{array}$

$\begin{array}{lll}3.8 & \text { Ethical issues } & 40\end{array}$ 
4. Results

4.1 Sociodemographic characteristics

4.2 Anthropometric characteristics

4.3 Physiological parameters

4.4 Physical characteristics

4.5 Performance

4.6 Correlation of performance of short distance athletes with their physiological parameters and physical characteristics Short distance athletes

4.7 Correlation of performance of swimmers with their physiological parameters and physical characteristics Swimmers

4.8 Assessment of Nutritional Status 55

4.8.1 Calorie Adequacy

4.8.1.1 Calorie adequacy of short distance athletes

4.8.1.2 Calorie adequacy of swimmers 56

Calorie adequacy of volleyball players

4.8.2 Protein adequacy

4.8.2.1 Protein adequacy of short distance athletes 60

4.8.2.2 Protein adequacy of swimmers.

Protein adequacy of volleyball

players 
4.8.3.1 Micronutrient adequacy of short

distance athletes

4.8.3.2 Micronutrient adequacy of swimmers

4.8.3.3 Micronutrient adequacy of volleyball

players

5. Discussion

5.1 Sociodemographic characteristics

5.2 Anthropometric characteristics

5.3 Physiological parameters

5.4 Physical characteristics

5.5 Performance

5.6 Correlation of performance of short distance athletes and swimmers with physiological parameters and physical characteristics

5.7 Assessment of nutritional status

6. Conclusions

7. References

8. Appendices

8.1 Appendix I - Sociodemographic characteristics

8.2 Appendix II - Record of physiological and physical 
8.3 Appendix III - Dietary recall non-competitive and competitive season

8.4 Appendix IV - Activity record non-competitive and competitive seasons

8.5 Appendix V -Consent Foam

8.6 Appendix VI -Certificate of ethical clearance

8.7 Appendix VII - Abstract presented at the $124^{\text {th }}$ Annual

Scientific Sessions of the Sri Lanka

Medical Association (OP 35)

8.8 Appendix VIII - Abstract presented at the $24^{\text {th }}$ Annual

Scientific Sessions of the physiological society of Sri Lanka (OC4)

8.8 Appendix IX - Abstract presented at the $125^{\text {th }}$ Annual

Scientific Sessions of the Sri Lanka

Medical

Association (pp108) 


\section{List of Tables}

Table 4.1 Socio- demographic characteristics of the Study sample

Table 4.2 Distribution of gender according to age group in the Total Study sample

Table 4.3 Summary of socio-demographic characteristics according to the type of sport involved

Table 4.4 Comparison of anthropometric characteristics (means $\pm \mathrm{SD}$ ) between short distance athletes, swimmers and volleyball players in the non-competitive season.

Table $4.5 \quad$ Comparison of anthropometric characteristics (mean \pm SD) between short distance athletes, swimmers and volleyball players in the competitive season.

Table 4.6 Comparison of physiological variables (mean \pm SD) between short distance athletes, swimmers and volleyball players in the non- competitive season.

Table 4.7 Comparison of physiological variables (mean \pm SD) between short distance athletes, swimmers and volleyballplayers in the competitive season.

Table 4.8 Comparison of physical variables (mean $\pm \mathrm{SD}$ ) between short distance athletes, swimmers and volleyball players in the non- competitive season 
Table 4.9 Comparison of physical variables (mean \pm SD) between short distance athletes, swimmers and volleyball players in the competitive season

Table 4.10 Comparison of performance of sports personnel involved in individual sports (short distance athletes and swimmers) between competitive and non -competitive season.

Table 4.11 Correlation of performance of short distance athletes with their physiological parameters and physical characteristics

Table 4.12 Correlation of performance of swimmers with their physiological parameters and physical characteristics

Table 4.13 Micro nutrient adequacy of short distance athletes in the non-competitive season

Table 4.14 Micro nutrient adequacy of short distance athletes in the competitive season.

Table 4.15 Micro nutrient adequacy of swimmers in the noncompetitive season

Table 4.16 Micro nutrient adequacy of swimmers in the competitive season 
Table 4.17 Micro nutrient adequacy of volleyball players in the noncompetitive season

Table 4.18 Micro nutrient adequacy of volley ball players in the competitive season 


\section{List of Figures}

Figure 4.1 Age distribution of short distance athletes in the study sample

Figure 4.2 Age distribution of swimmers in the study sample

Figure 4.3

Age distribution of volleyball players in the study sample

Figure 4.4.(a) Percentage daily calorie adequacy of short distance athletes in the non-competitive season

Figure 4.4.(b) Percentage daily calorie adequacy of short distance athletes in the competitive season

Figure 4.5.(a) Pecentage daily calorie adequacy of swimmers in the non- competitive season

Figure 4.5.(b) Pecentage daily calorie adequacy of swimmers in the competitive season

Figure 4.6.(a) Pecentage daily calorie adequacy of volley ball players in the non-competitive season

Figure 4.6.(b) Pecentage daily calorie adequacy of volleyball players in the competitive season

Figure 4.7.(a) Percentage daily protein adequacy of short distance athletes in the non-competitive season

Figure 4.7.(b) Pecentage daily protein adequacy of short distence athletes in the compititive serason

F i g u re 4. 8. (a) Pecentage daily protein adequacy of swimmers in 
Figure 4. 8. (b) Pecentage daily protein adequacy of swimmers in the competitive season

Figure 4.9.(a) Pecentage daily protein adequacy of volleyball players in the non-competitive season

Figure 4.9.(b) Pecentage protein adequacy of volleyball players in the competitive season 


\section{Acknowledgements}

This research project was initiated with the supervision of Late Prof. M T M Jiffrey (Former Deputy Chairman UGC), Dr. (Ms) P T R Makuloluwa (Senior Lecturer, Department of Physiology, Faculty of Medical Sciences, University of Sri Jayewardenaepura) and Dr. Geethanjan Mendis (Former Director General in Institute of Sports Medicine). I would like to appreciate their kind hearted cooperation extended towards me to carry out the project.

I am extremely indebted to Dr .Sudharshani Waslathanthiri ,Senior Lecture, Department of Physiology, Faculty of Medicine, University of Colombo for accepting to supervise the project and giving me the opportunity to continue with the work under her direction on the request of Dr .P T R Makuloluwa in the event of the sudden demise of Prof. M T M Jiffrey. She encouraged me and guided me throughout the writing of the theses and was always there to listen to me and advice me patiently.

I would like to express my gratitude to Prof. S.Sivayogan (Senior Lecture, Department of Community Medicine, Faculty of Medical Sciences, University of Sri Jayewardenepura) for guiding me with the statistical analysis, Mr. Peraymarathna Rathnasinghe, (Statistician, Family Health Bauru) for helping me with the data analysis and, Dr. K D R R Silva( Dean, Faculty of Livestock Fisheries \& Nutrition Wayamba University of Sri lanka )for allowing me to use their computer food base software for my nutritional analysis. 
I specially thank Mr. Thisara Jayasekara of National Institute of Sports Sciences who gave his valuable time and inputs throughout the project.

I wish to thank Late Mr. Lakshman De Alwis (Former National Athletic coach), Mr Julion Boeling (swimming coach), and Mr. A.A .Jayathissa (Volleyball coach) for their support and assistance in data collection in sports personnel and Mr.Rohana Rathnayaka (Athletic coach) for his support in sports related clarifications of observations throughout the research.

I wish to thank all the sports personnel who were involved in this research project and the employees at the Institute of Sports Medicine for their support. A special thank you goes to Mrs. Amila de Silva of National Institute of Sports Sciences and Mr. Ruwan Samerakody for helping me in different ways.

I appreciate the support of undergraduates of the Faculty of Livestock Fisheries \& Nutrition, Wayamba University of Sri Lanka during the period 2009-2010 for helping me with nutritional data presentation and analysis. I am extremely grateful to my second sister, Janadari for helping me to find research papers and to my elder sister Asha for her kind hearted support offered to fulfill my family responsibilities.

I am always indebted to my mother and father, my husband Ajith and the two kids, daughter Yasasvi and son Yenul for their patience and tolerance especially when my responsibilities were not fulfilled up to their expentation during this period. 


\title{
Performance of National and International Level Sports Personnel and its association with Physical and Physiological Characteristics, and Nutritional Aspects.
}

\section{Vindya Ganegama Arachchi}

\begin{abstract}
Important test components for fitness evaluation include assessment of physical and physiological characteristics which determine the physical performance capacity and metabolic efficiency of sports personnel. Optimum nutrition is also an important factor for good sports performance. The purpose of this study was to describe the anthropometric measurements (weight, height, BMI, fat percentage), physiological parameters (resting heart rate, maximum heart rate, systolic blood pressure, diastolic blood pressure, $\mathrm{VO}_{2} \mathrm{max}$ ), physical characteristics (strength, power, flexibility, endurance) and nutritional status of national and international level Sri Lankan short distance athletes, swimmers and volleyball players. The parameters were measured in two training seasons i.e. non-competitive and competitive seasons targeting the $10^{\text {th }}$ South Asian Federation games held in Sri Lanka. The sample included 36 short distance athletes, 38 swimmers and 48 volleyball players. Anthropometric characteristics were determined using standard test procedures. Physiological characteristics were determined using $\mathrm{K} 4 \mathrm{~b}^{2}$ specific software developed by Cosmed Srl-Italy. Physical characteristics were determined
\end{abstract}


by procedures specific to each parameter. Anthropometric characteristics of sports personnel studied appeared to be satisfactory. When anthropometric characteristics were compared between the three groups of sports personnel studied, the volleyball players were taller and had a higher percentage of body fat when compared to short distance athletes and swimmers. $\mathrm{VO}_{2}$ max levels of athletes showed significant improvement with training. The $\mathrm{VO}_{2} \mathrm{max}$ was highest in short distance athletes when compared to swimmers and volleyball players. The highest strength was recorded in short distance athletes, highest power and flexibility in volleyball players and a very low endurance level in swimmers. The mean sports performance of sports personnel engaged in individual sports (short distance athletics and swimming) was significantly higher $(\mathrm{P}<0.001)$ in the non-competitive season when compared to the competitive season. Pearson correlation coefficients (r) calculated to determine the relationship between the performance and each of the physiological variables tested showed a significant correlation between $\mathrm{VO}_{2} \max$ and performance $(\mathrm{r}=0.65 ; \mathrm{p}<0.05)$ in international level short distance athletes in the non-competitive season. In the competitive season, a significant correlation was seen between maximum heart rate and performance $(r=0.48 ; \mathrm{P}<0.05)$ only in national level players. Among the physical characteristics, there was a highly significant correlation between the power and performance $(\mathrm{r}=0.81 ; \mathrm{P}<0.001)$ and a significant correlation between endurance and performance $(\mathrm{r}=0.52 ; \mathrm{P}<0.05)$ in the non-competitive season in national level short distance athletes. Nutritional analysis showed that calorie, protein and micronutrient intake was not satisfactory in all sports personnel both in competitive and noncompetitive seasons. 